\title{
SPECIFIČNOSTI VRŠENJA INSPEKCIJSKIH FUNKCIJA U OBLASTI RADA, RADNIH ODNOSA I SIGURNOSTI NA RADU
}

Izv. prof. dr. sc. Ivo Rozić*

Doc. dr. sc. Emir Mehmedović**
UDK: 331.4

https://doi.org/10.30925/zpfsr.40.2.8

Ur.: 10. travnja 2019.

Pr.: 30. svibnja 2019.

Pregledni znanstveni rad

\section{Sažetak}

U radu se analizira pitanje intenziteta vršenja temeljnih funkcija inspekcijskog nadzora - preventivne, korektivne i represivne funkcije u kontekstu inspekcije rada. Iako predstavljaju funkcije zajedničke svim oblastima inspekcijskih nadzora, obim $i$ intenzitet vršenja navedenih funkcija ovisi od oblasti inspekcijskog nadzora. Pored toga, u okviru određene oblasti, obim korištenja navedenih funkcija inspekcijskog nadzora zavisi $i$ o stupnju razvijenosti ( $i$ kvalitete) sektorske politike, ali $i$ oblika organiziranja inspekcijske službe. Zbog njegove društvene i gospodarske važnosti, kao i subjekata na koje utječe (gospodarskih društava i uposlenih), oblast rada, radnih odnosa i sigurnosti na radu traži prilagođen pristup u inspekcijskom nadzoru. U oblasti rada, radnih odnosa $i$ sigurnosti na radu preventivna funkcija ima, ili bi barem trebala da ima, dominantn(ij)u ulogu u odnosu na korektivnu i represivnu funkciju inspekcijskog nadzora.

Ključne riječi: inspekcijske službe; sektorska politika; preventivna funkcija; korektivna funkcija; represivna funkcija.

\section{UVOD}

Inspekcijske službe svoj društveni značaj i ulogu prvenstveno ostvaruju vršeći upravni nadzor, koji je, nakon poslova izvršavanja zakona i drugih propisa, jedan od najvažnijih poslova uprave. ${ }^{1}$ Poslovi inspekcijskog nadzora vrše se prvenstveno radi osiguranja dosljedne primjene propisa, ali i radi identificiranja njihovih slabosti i nedostataka u praksi u cilju njihove prilagodbe društvenoj realnosti. ${ }^{2}$ Inspekcijske

* Dr. sc. Ivo Rozić, izvanredni profesor, Pravni fakultet Sveučilišta u Mostaru, ivo.rozic@pf.sum. ba.

** Dr. sc. Emir Mehmedović, docent, Fakultet za upravu Univerziteta u Sarajevu, emir. mehmedovic@fu.unsa.ba.

1 Dedić, S., Upravno pravo Bosne i Hercegovine, Bihać-Sarajevo, Pravni fakultet u Bihaću, Magistrat, 2000., str. 253.

2 Perišić, S., Organizacija i principi inspekcijskog nadzora, doktorska disertacija, Niš, Pravni 
službe pri vršenju nadzora mogu djelovati poduzimanjem preventivnih, korektivnih i represivnih mjera ${ }^{3}$ te se, sukladno njemu, funkcije inspekcijskog nadzora nazivaju: 1) preventivna, 2) korektivna i 3) represivnu funkcija. Svaka od navedenih funkcija ima svoj raison d'être (razlog postojanja), svoje specifičnosti i domete.

Iako navedene funkcije obavljaju sve inspekcijske službe, u pojedinim oblastima inspekcijskog nadzora, ovisno o objektu zaštite, njegovom društvenom značaju i javnoj politici (u određenom sektoru), u fokusu pažnje mogu biti određene funkcije, dok druge mogu imati manji značaj i utjecaj.

Oblast rada, radnih odnosa i sigurnosti na radu jedna je od najvažnijih oblasti društvenog života. Nadzor nad primjenom propisa koji reguliraju ovu oblast vrši (isključivo ili u najvećem dijelu ${ }^{4}$ ) inspekcija rada. ${ }^{5}$ Inspekcija rada snažan je i kvalitetan instrument za učinkovitu provedbu politika u oblasti rada i sigurnosti na radu. Kvalitetna inspekcija rada istodobno je zaštitnik, ali i promotor radnog zakonodavstva i javne politike u oblasti rada.

Postupajući u okviru svojih nadležnosti inspekcijske službe inspekcije rada, svojim načinom rada, poduzetim aktivnostima i mjerama mogu dati važan doprinos u osiguranju boljih i sigurnijih uvjeta rada, osiguranju „fer“" konkurencije, pa čak i omogućavanju učinkovitije organizacije rada i poslovanja poslodavaca. Međutim, utjecaj inspekcijskih službi može biti i negativan, čak i onda kada su inspekcijske aktivnosti i mjere poduzete u okviru zakonom propisanih ovlasti. Kao posljedica toga može doći do negativnih efekata po društvo, a posebice gospodarstvo. Tako se, npr. nepotrebnim ili nerazmjernim izricanjem strožih upravnih mjera (npr. zabranom rada) izravno utječe na poslovanje poduzeća, što posljedično ima negativne društvene i gospodarske implikacije. Nažalost, pitanju utjecaja aktivnosti inspekcije rada na društvo i gospodarstvo ne pridaje se dužna pažnja ni u znanstvenim ni u stručnim radovima. ${ }^{6}$

Kako je pitanje intenziteta vršenja određenih funkcija izravno povezano s utjecajem inspekcije rada na društvo i gospodarstvo, u nastavku rada ćemo izložiti opće karakteristike funkcija inspekcijskog nadzora, nakon čega ćemo razmotriti njihove specifičnosti u oblasti rada, radnih odnosa i sigurnosti na radu.

fakultet u Nišu, 2011., str. 74-75.

3 Ivošević, Z., Radno pravo, 8. izmenjeno i dopunjeno izdanje, Beograd, Pravni fakultet Univerziteta Union u Beogradu i Javno preduzeće Službeni glasnik, 2015., str. 340.

4 U velikom broju država inspekcijski nadzor u oblasti sigurnosti na radu vrše specijalizirani inspektori zaštite na radu.

$5 \mathrm{Na}$ temelju analize radnog zakonodavstva najvećeg broja država članica Međunarodne organizacije rada, a posebice država Europske unije i država regije može se ustvrditi da u standardne poslove inspekcije rada spadaju nadzor u oblasti radnih odnosa te u oblasti zdravlja i sigurnosti na radu.

6 Pires, R., Labour inspection and development: Some reflections, Geneva, International Labour Organisation, 2011., str. 1. 


\section{FUNKCIJE INSPEKCIJSKOG NADZORA}

\subsection{Preventivna funkcija inspekcijskog nadzora}

Cilj preventivne funkcije inspekcijskog nadzora je sprječavanje, prevencija povrede propisa. Ona se provodi radi pravovremenog sprječavanja neželjenih posljedica, odnosno nepravilnosti, koje predstavljaju odstupanje od društvenih pravila reguliranih propisima. ${ }^{7}$ Nepravilnosti, kao takve, ponašanja su suprotna društveno prihvaćenim vrijednostima koje su zaštićene odgovarajućim pravnim propisima.

Preventivna funkcija, kao proaktivna djelatnost, može se ostvarivati različito, a najtipičniji su pravodobno, stručno i detaljno informiranje subjekata nadzora o pravilima i propisima koje su dužni primjenjivati te davanje odgovora na upite subjekata nadzora o odgovarajućem postupanju u određenim situacijama. Preventivno djelovanje inspekcijske službe može se ostvariti putem izravnog ukazivanja subjektima nadzora na obveze pridržavanja propisa, na štetne posljedice (po njih i širu zajednicu) u slučaju nepridržavanja propisa, sugeriranjem mjera za otklanjanje uzroka koji mogu dovesti do štetnih posljedica, informiranjem o djelotvornijem načinu izvršenja propisa i sl.

Paradoks preventivnog djelovanja očituje se u tome da je, kao posljedica kvalitetnog i učinkovitog obavljanja preventivne funkcije, važnost rada i djelovanja inspekcijskih službi manje vidljiv. Naime, što inspekcijske službe kvalitetnije i učinkovitije provode preventivnu funkciju manji je broj povreda propisa, pa samim time i njihov negativni utjecaj na društvo. Iako je rezultate preventivnog djelovanja teško kvantitativno iskazati, ipak se može, uspoređujući broj povreda kontroliranog propisa prije neke preventivne kampanje, tijekom njenog trajanja, neposredno nakon njenog okončanja te $u$ određenom periodu nakon njenog okončanja, doći do signifikantnih podataka o uspješnosti preventivnog djelovanja. Također, do navedenih podataka može se doći i usporedbom s rezultatima u oblastima nadzora gdje se preventivna aktivnost nije provodila. Efekti preventivnog djelovanja inspekcijskih službi mogu se ogledati u činjenici da subjekti nadzora, svjesni da su njihove aktivnosti predmet nadzora (ili to barem mogu biti), dodatno paze na zakonitost svoga djelovanja. ${ }^{8}$

U određenim okolnostima i represivna funkcija, kao posebna funkcija inspekcijskog nadzora, nalazi se u funkciji prevencije. Naime, sankcija nema isključivo funkciju kažnjavanja, nego ima i funkciju generalne i specijalne prevencije. Generalna prevencija ${ }^{9}$ preventivni je utjecaj sankcije na javnost (širi krug osoba), dok specijalna

7 U Zakonu o inspekcijama Federacije Bosne i Hercegovine preventivna funkcija definirana je kao inspekcijski posao čiji je smisao poduzimanje mjera i radnji radi sprječavanja povrede propisa, čl. 2., st. 1., t. 4.), podt. b).

8 Borković, I., Upravno pravo, Zagreb, Narodne novine, 2002., str. 114.

9 Teorije generalne prevencije svrhu kažnjavanja određuju kao utjecaj na javnost radi sprječavanja počinjenja kaznenih djela. One su primarno teorije o prijetnji kaznom, ali nužno $i$ o izricanju i izvršenju kazne jer o tome ovisi efikasnost propisane prijetnje. Bojanić, I., Mrčela, M., Svrha kažnjavanja u kontekstu šeste novele Kaznenog zakona, Zagreb, Hrvatski ljetopis za kazneno pravo i praksu, vol. 13, 2/2006, str. 438. 
prevencija ${ }^{10}$ preventivni je utjecaj sankcije na izvršioca, jer jednom izrečena sankcija može djelovati na subjekt nadzora da više ne vrši povrede propisa.

Ideal inspekcije je njen nestanak, odnosno ostvarivanje takvog nivoa poštovanja zakona i drugih propisa subjekata nadzora da ne postoji potreba za vršenjem korektivne i represivne funkcije inspekcijskih službi. Taj ideal vjerojatno će biti praktično neostvariv, budući da nepravilno postupanje nije samo rezultat pogreški, neznanja i neinformiranosti subjekata nadzora, nego nerijetko, (svjesne i voljne) namjere da se, iz određenog razloga, počini nepravilnost. I pored toga, pri utvrđivanju misije inspekcijskih službi mora se poći od toga da ona treba biti prvenstveno preventivna i proaktivna. $^{11}$

\subsection{Korektivna funkcija inspekcijskog nadzora}

Korektivna funkcija djelatnost je inspekcijske službe čiji je smisao da utvrđenu nepravilnost ispravi, otkloni ili umanji njene posljedice. Za razliku od preventivne funkcije, koja je proaktivna, korektivna (kao i represivna) funkcija su reaktivne djelatnosti inspekcijskih službi.

Nepravilnošću je povrijeđen društveni interes zaštićen propisom te, stoga, postoji i društveni interes da se ona ispravi, otkloni ili umanje njene posljedice, koliko je to moguće. Korektivna funkcija je nužna i konstantna, i u odnosu na nju postoji najmanji obim variranja u intenzitetu njenog vršenja. Naime, dok intenzitet vršenja druge dvije (preventivne i represivne) funkcije u određenoj mjeri zavise o politici u određenoj oblasti, kod korektivne funkcije to nije tako nego se u svakom slučaju evidentiranog kršenja treba izvršiti korekcija. Ukoliko inspekcijske službe ne vrše korektivnu funkciju, to znači da one ne obavljaju svoju temeljnu djelatnost. Neučinkovita korektivna funkcija ukazuje na nepoštovanje zakona.

Nastanak nepravilnosti je nužan uvjet za primjenu sankcije, koja je kazna zbog ponašanja suprotnog dispoziciji pravne norme. ${ }^{12}$ Do nastanka nepravilnosti može doći svakom radnjom kojom se postupa suprotno pravnoj normi, bilo činjenjem ili nečinjenjem.

U suvremenoj općoj teoriji prava po pitanju pravne prirode korektivne funkcije postoje dva shvaćanja: sankcionističko i obligaciono-pravno. Prema sankcionističkom shvaćanju korekcija, odnosno popravljanje štete se smatra isključivo kao sankcija za protupravno ponašanje, dok je prema obligaciono-pravnom shvaćanju, korekcija obligaciona obveza stvorena protupravnim postupanjem. ${ }^{13}$

10 Prema teorijama specijalne prevencije, svrha kazne je odvraćanje počinitelja od budućih kaznenih djela. Specijalnu prevenciju kao svrhu kazne izričito spominje i članak 50. KZ-a kao utjecaj na počinitelja da ubuduće ne čini kaznena djela. Specijalna prevencija može se promatrati u negativnom aspektu kao individualno zastrašivanje i sprječavanje počinitelja da ponovo počini kazneno djelo (zatvaranjem kod kazni lišenja slobode) te u pozitivnom aspektu kao osposobljavanje počinitelja za život bez počinjenja kaznenih djela (popravljanje, resocijalizacija). Ibid., str. 436.

11 Anđelković, B., Uloga nadzora i inspekcije zaštite na radu u uslovima tranzicije na tržišnu ekonomiju - iskustva Republike Srbije, Niš, Safety Engineering, vol. 4, 1/2014, str. 54.

12 Lukić, R., Košutić, B., Uvod u pravo, XIX. izdanje, Beograd, Službeni list SCG, 2003., str. 273.

13 Burazin, L., Hegelov prinos suvremenom odštetnom pravu sa stajališta opće teorije i filozofije 
Korektivna funkcija podrazumijeva aktivnost inspekcijske službe usmjerenu na uklanjanje nepravilnosti i nedostataka utvrđenih u inspekcijskom nadzoru, odnosno zabranu daljnjeg poduzimanja radnji i aktivnosti koje su u suprotnosti s propisima čiju primjenu nadzire inspekcijska služba. Korektivnu funkciju inspekcijska služba ostvaruje donošenjem rješenja kojim subjektu nadzora nalaže ili zabranjuje određeno činjenje.

\subsection{Represivna funkcija inspekcijskog nadzora}

Represija, odnosno sankcija djelatnost je inspekcijske službe kojom se kažnjava subjekt nadzora zbog nepravilnosti, odnosno ponašanja koje je protivno dispoziciji. To je prinudna mjera koju tijelo uprave primjenjuje nad prekršiteljem dispozicije. ${ }^{14}$ Pojam represije $u$ širem smislu obuhvata ne isključivo sankcioniranje, nego i prijetnju sankcijom. ${ }^{15}$ Ovisno o politici u određenoj oblasti, kao i o načinu organiziranja inspekcijskih službi, zavisi u kojem intenzitetu će se vršiti ova funkcija. Ukoliko je akcenat na preventivnom djelovanju, funkcija sankcioniranja neće biti dominantno izražena. Čak i ako je sankcija izrečena, ona, prvenstveno, ima za cilj specijalnu i generalnu prevenciju, odnosno upozorenje je subjektu nadzora koji je počinio nepravilnost, ali i svim drugim subjektima nadzora da će u slučaju počinjene nepravilnosti biti sankcionirani. Kažnjava se ne samo zbog toga što je počinjena nepravilnost, nego i zbog toga da se ne bi ponovo počinila. ${ }^{16}$

Represivna funkcija ostvaruje se kažnjavanjem subjekta nadzora zbog povreda propisa koje inspekcijska služba nadzire. Kažnjavanje se ostvaruje u prekršajnom postupku, na način da inspekcijska služba subjektu nadzora koji je počinio povredu propisa može izdati prekršajni nalog ili podnijeti prekršajnu prijavu nadležnom sudu. Izuzetno, represivnu funkciju inspekcijska služba može ostvarivati i iniciranjem stegovnog postupka protiv uposlenog čijom krivnjom je došlo do kršenja propisa subjekta nadzora, odnosno podnošenjem kaznene prijave, ukoliko inspektor utvrdi da određeno kršenje propisa subjekta nadzora ima elemente kaznene odgovornosti. Treba podsjetiti da je stegovna odgovornost poseban oblik pravne odgovornosti jer se odnosi samo na uposlene i to u vezi s njihovim radno-pravnim statusom. Međutim, s obzirom na to da ta radnja istovremeno može biti i povreda službene ili radne dužnosti, ali i kazneno djelo, odnosno prekršaj, otvara se dilema o pravičnosti dvostrukoga kažnjavanja za isto djelo. Ova dilema riješena je tako što je propisano da utvrđivanje kaznene ili prekršajne odgovornosti ne isključuje stegovnu odgovornost za isto djelo. Stoga uposleni može za isto djelo odgovarati i stegovno, ali i kazneno, odnosno prekršajno. U oblasti radnog zakonodavstva, s obzirom na društveni značaj rada, normirana je i kazneno-pravna odgovornost i sankcija za kršenje određenih prava uposlenih na osnovu radnog odnosa. ${ }^{17}$

prava, Zagreb, Hrvatska pravna revija, 2/2011, str. 83.

14 Lukić, R., Košutić, B., op. cit., str. 274.

15 Stojanović Z., Preventivna funkcija krivičnog prava, Beograd, Crimen - Časopis za krivične nauke, $1 / 2011$, str. 4.

16 loc. cit.

17 Krivičnom sankcijom štite se određena prava zaposlenika i građana po osnovu radnog odnosa. 
Iako je cilj inspekcijskog nadzora usklađivanje postupanja subjekata nadzora s propisima, inspekcijske službe ne mogu funkcionirati isključivo na represivnoj funkciji, odnosno na prinudi i strahu od prinude. Naprotiv, inspekcijske službe usklađenost između činjeničnog i pravnog stanja moraju ostvarivati izgradnjom dobrih odnosa i suradnje sa subjektima nadzora, što nesumnjivo ukazuje da funkcija represije nije primarna. Posebno, represija ne smije biti izražena kada postoje objektivne okolnosti koje onemogućavaju postupanje subjekata nadzora u skladu s propisima. U tim situacijama inspektori trebaju, ukoliko je to moguće i koliko je to moguće, pružiti podršku subjektima nadzora da usklade svoje postupanje s propisima, prije nego da ih samo sankcioniraju. ${ }^{18}$

Konačno, postoji korelacija između oblika organiziranja i intenziteta vršenja funkcija inspekcijskih službi. U principu, korektivna i represivna funkcija dominantnije su u slučaju funkcionalnog organiziranja inspekcijskih službi, dok je preventivna funkcija dominantnija u resornom modelu organiziranja. Naime, kod funkcionalnog modela organiziranja više inspekcijskih službi zajedno rade i djeluju te je težište rada na provjeri usklađenosti postupanja sa zakonom, a manje na provođenju politika koje kreira resorno ministarstvo, uključujući i politiku preventivnog djelovanja. Nasuprot tome, kod resornog modela organiziranja, inspekcijska služba je organizacijski vezana za resorno ministarstvo te politiku resornog ministarstva mnogo više doživljava kao svoju, što utječe da se ona bolje i dosljednije provodi, a posebno vezano za intenzivnije vršenje preventivne funkcije. ${ }^{19}$

\section{SPECIFIČNOSTI INTENZITETA VRŠENJA FUNKCIJA NA PRIMJERU INSPEKCIJE RADA}

Kao što je već rečeno, svaka oblast inspekcijskog nadzora ima svoje posebnosti koje su određene njenim ciljem i specifičnim društvenim odnosima reguliranim pravnim normama nad čijom primjenom nadzor vrši inspekcijska služba. Te posebnosti mogu utjecati na intenzitet vršenja određenih funkcija inspekcijskog nadzora.

Tako se u okviru krivičnih djela protiv radnih odnosa, koja su svrstana odmah iza grupe krivičnih djela protiv slobode i prava građana, omogućuje zaštita određenih prava iz radnih odnosa, kao i prava koja proizilaze iz socijalnog osiguranja, i to: prava vezanih za povrede ravnopravnosti u zapošljavanju, povrede prava iz radnog odnosa, povrede prava za vrijeme privremene nezaposlenosti, povrede i zloupotrebe prava iz socijalnog osiguranja, neizvršavanja odluke o vraćanju na rad, te nepreduzimanja mjera zaštite na radu. Ostala prava, koja po osnovu rada pripadaju zaposlenicima, štite se posredno u okviru drugih grupa krivičnih djela (npr. krivična djela protiv slobode i prava građana, krivična djela protiv opće sigurnosti i imovine, krivična djela protiv privrede). Ono što karakterizira ova krivična djela je nastojanje društva da naglasi poseban značaj zaštite prava iz radnog odnosa, kao značajnog segmenta prava koja pripadaju građanima. Dedić, S., Gradaščević-Sijerčić, J., Radno pravo, 2. izmijenjeno i dopunjeno izd., Sarajevo, Magistrat, 2005., str. 463-464.

18 Jacobs, S., Cordova, C., Good Practices for Business Inspections - Guidelines for Reformers, Washington, World Bank Group, Small and Medium Enterprise Department, 2006., str. 4.

19 Rozić, I., Mehmedović, E., Uticaj organizacije inspekcijskih službi na učinkovitost i ostvarivanje funkcije inspekcijskog nadzora - primjer inspekcija rada u Bosni i Hercegovini, Godišnjak Pravnog fakulteta Univerziteta „Džemal Bijedić“" u Mostaru, god. I, 1/2017, str. 121-123. 
Takav je slučaj i u oblasti rada, radnih odnosa i sigurnosti na radu. U usporednom pravu, u ovoj oblasti, izdiferencirala su se dva pristupa, i to ,pristup sankcija”, izražen npr. u Sjedinjenim Američkim Državama, Brazilu, Nizozemskoj, prema kojem je prvenstveni zadatak inspektora sankcioniranje subjekata nadzora zbog kršenja propisa, odnosno izricanje sankcija zbog nepoštovanja pravila i propisa. Osnovna postavka ovog modela je da će subjekti nadzora poštovati propise kada im je to „isplativo“, odnosno da kada je velika vjerojatnost da će njihovo nepridržavanje propisa biti utvrđeno i sankcionirano inspekcijskim nadzorom i da će, u tom slučaju, rizik od troškova kazne prevagnuti nad eventualnom koristi od nepoštovanja zakona. Sukladno njemu, od inspektora se očekuje „traženje“ nepravilnosti i izricanje propisane kazne.

Drugi pristup je ,pristup poštovanja zakona” (npr. u Ujedinjenom Kraljevstvu, Njemačkoj i Japanu), prema kojem je zadatak inspektora rada, prije svega, prevencija, gdje se nastoji promovirati poštovanje zakona, uz ozbiljnu prijetnju sankcijama ukoliko se subjekt nadzora ne pridržava zakonom propisane obveze.

Oba ova pristupa baziraju se na različitom intenzitetu vršenja temeljnih funkcija inspekcijskog nadzora.

\subsection{Preventivna funkcija inspekcije rada}

Primarna uloga inspekcije rada je osiguranje poštovanja odredbi nacionalnoga radnog zakonodavstva. ${ }^{20} \mathrm{Da}$ bi se to ostvarilo od suštinskog značaja je razvijanje svijesti subjekata nadzora o obvezi poštovanja propisa, a posebice o njihovim pravima i obvezama. ${ }^{21}$ Razvijanje svijesti o obveznosti primjene propisa značajna je aktivnost inspekcije rada, ${ }^{22}$ budući da je preduvjet uspješnosti politike prevencije učešće svih

20 Čl. 3. st. 1.) t. a) Konvencije o inspekciji rada, broj 81.

21 Danas je opšteprihvaćeno da je bolje sprečiti nego sankcionisati ili kažnjavati. (...) Naglasak se sve više stavlja na preventivnu intervenciju kao jedan vid korektivne intervencije. Naravno, tradicionalno 'sprovođenje propisa', naime različiti vidovi tehničke inspekcije, $i$ dalje $u$ značajnoj meri doprinosi prevenciji nezgoda i štetnosti za zdravlje, posebno ako je praćeno savetima $i$ komentarima za poslodavce i radnike. Rihthofen, V. fon, Inspekcija rada - Vodič za profesiju, Beograd, Ministarstvo rada, zapošljavanja i socijalne politike Republike Srbije, 2005., str. 18-19.

22 Četvrti princip se odnosi na to da inspekcija rada treba da poveća svoju orjentaciju i naglasak na prevenciji. Govoriti o prevenciji u kontekstu zaštite na radu podrazumeva, pre svega, jedan odlučan napor da se izbegnu neočekivani događaji, sporovi, povrede, konflikti i profesionalna oboljenja tako što će se obezbediti poštovanje postojećih zakona. Danas, preventivna orijentacija ima za svoj krajnji cilj razvoj kulture prevencije u paradigmi socijalne i politike rada. Ona takođe sve više teži ka jednom širem cilju, da se pojedincima omogući da vode dug, produktivan i zdrav život, a u isto vreme da se smanje eksponencijalni rastući troškovi koji su rezultat neprevencije, ili da se smanje gubici koje neočekivani događaji izazivaju kod pojedinaca, preduzeća i društva u cjelini. Prevencija, u današnjem svetu rada, sve više se podržava ne samo zbog svojih kratkoročnih ili srednjoročnih prednosti, već i zbog toga što ona podržava dugoročne ekonomske i socijalne ciljeve politike na nacionalnom, sektorskom i nivou preduzeća, jer na taj način se održava radna sposobnost, produktivnost i kvalitet, motivacija zaposlenih $i$ bezbednost zaposlenja. Zato se na prevenciju gleda kao na presudan preduslov ne samo da bi pojedinci vodili dostojanstven život u društvu već i da bi preduzeća bili uspešni konkurenti na (globalnom) tržištu. Stoga se prevencija sve više definiše kao celovit, 'otvoren' ili pluralistički koncept, koji ima za cilj da izbegne višestruke tehničke, socijalne, zdravstvene, 
izravno zainteresiranih strana i pojedinaca. ${ }^{23}$

Zbog društvenog i gospodarskog značaja rada te zdravlja i sigurnosti na radu preventivna funkcija inspekcije rada je znatnije izražena nego kod većine drugih inspekcijskih službi. Termini „sigurnost“, odnosno „zaštita“ na radu ukazuju na preventivno aktivnost. ${ }^{24}$ Općenito promatrajući, što je neka oblast društveno značajnija preventivna funkcija je razvijenija, odnosno, postoji korelacija između težine eventualnih posljedica nepravilnosti i funkcija inspekcijskog nadzora. Može zvučati paradoksalno, ali što su aktivnosti inspekcije rada u preveniranju nepravilnosti, a posebice nesreća na radu i profesionalnih oboljenja uspješnije, umanjuje se očigledna činjenica da su njegove (inspekcije rada - op. aut.) aktivnosti od vitalnog značaja " ${ }^{25}$ Drugim riječima, što je efikasnija preventivna funkcija inspekcije rada broj i težina nesreća je manji, što u javnosti posljedično umanjuje njen značaj. Nasuprot tome, veliki broj nesreća, posebno onih sa smrtnim ishodom, utječe na društvenu percepciju značaja preventivne funkcije inspekcije rada. Imajući u vidu da su oblasti rada i zdravlja i sigurnosti na radu od velikog društvenog i gospodarskog značaja preventivna funkcija bi morala biti izraženija u odnosu na korektivnu i represivnu funkciju inspekcijskog nadzora.

Inspekcija rada razvijanje svijesti, kao preventivnu djelatnost može vršiti informiranjem i savjetovanjem uposlenika, poslodavaca, ali i šire javnosti putem informativnih kampanja, zatim, prethodnom provjerom i odobrenjem otvaranja novih postrojenja ili proizvodnih pogona. ${ }^{26}$ Posebno je značajna preventivna aktivnost $\mathrm{u}$ sprječavanju industrijskih nesreća i profesionalnih oboljenja.

Najčešće se preventivna funkcija vrši informiranjem i savjetovanjem kako uposlenika tako i poslodavaca. ${ }^{27}$ Ovaj zadatak inspekcije rada svoje utemeljenje nalazi u odredbama članka 3. stavak 1. točka (b) Konvencije o inspekciji rada, broj 81 i članka 6. stavak 1. točka (b) Konvencije o inspekciji rada u poljoprivredi, broj 129 , kojima je propisana obveza inspektora rada da poslodavcima i uposlenim daju tehničke informacije i savjete o najdjelotvornijim načinima poštivanja zakonskih odredbi. ${ }^{28}$ Da bi savjete i informacije prihvatili poslodavci i uposleni potrebno je da

psihološke i ekonomske opasnosti. Iz tog razloga, nedavno je došlo do velike promene u orijentaciji inspekcije rada ka usvajanju jednog šireg, multidisciplinarnog pristupa prevenciji. Ibid., str. 6.

23 ibid., str. 25 .

24 Učur, M., Neki posebni subjekti i odnosi po Zakonu o zaštiti na radu, Zbornik Pravnog fakulteta Sveučilišta u Rijeci, vol. 36, 1/2015, str. 533.

25 Rihthofen, V. fon, op. cit., str. 24.

26 Report of the Committee of Experts on the Application of Conventions and Recommendations (Article 19, 22 and 35 of the Constitution), International Labour Office, 50th Session, Geneva, 1966, Report III (Part IV): Labour inspection in industry, str. 210-212. (para. 53-59), <http:// www.ilo.org/public/libdoc/ilo/P/09661/09661 (1966-50-III-4).pdf>.

27 Profesionalni inspektori rada će pružiti uslugu poslodavcima koja će im pomoći da iznađu i uspostave najbolje prakse. (...) Takva usluga pružena kao javno dobro poslodavcima može biti neprocjenjiva za čileansku ekonomiju. Cesar Rosando, M., Of Labour Inspectors and Labour Judges: Chilean Labour Law Enforcement After Pinochet (And What the United States Can Do To Help) (Symposium), St. Louis University Law Journal, vol. 54, 497/2009, str. 518.

28 1. Zadaci sistema inspekcije rada jesu: ... (b) davati tehničke informacije i savjete poslodavcima 
inspekcija rada ima kredibilitet, a posebno profesionalno znanje i iskustvo. ${ }^{29}$

Preventivna funkcija inspekcije rada je posebno istaknuta u Preporuci o inspekciji rada u poljoprivredi, broj 133, kojom je u članku 14. stavak (1) preporučeno da svaka država članica poduzme ili promovira edukativne kampanje u cilju informiranja subjekata nadzora o propisima i potrebi njihove dosljedne primjene, o opasnostima za život i zdravlje uposlenih (poljoprivrednika), kao i odgovarajućim sredstvima za njihovu zaštitu. ${ }^{30}$ Preporuka navodi da takve edukativne kampanje mogu uključivati korištenje usluga promotora ili instruktora, distribuciju postera, letaka, magazina, časopisa, filmova, radijskih i televizijskih emisija, izložbi i demonstracija, uključivanja u obrazovni sustav predmeta „Higijena“, „Sigurnost“ i drugih srodnih predmeta, organiziranje konferencija o novim metodama rada ili novim supstancama i materijalima, učešće inspektora rada u edukativnim programima te organizaciju predavanja, debata, seminara, te nagradnih takmičenja. ${ }^{31}$ Učinkovito informiranje subjekata nadzora i javnosti općenito se može vršiti putem medija i IT komunikacija.

Vršeći preventivnu aktivnost Odbor viših inspektora rada (Senior Labour Inspectors' Committee-SLIC) Europske komisije redovito organizira kampanje o određenim pitanjima iz područja zaštite na radu. Od 2017. do 2019. provodi se kampanja zaštite na radu radnika zaposlenih putem agencija za privremeno zapošljavanje pod nazivom „Siguran i zdrav rad na privremenim poslovima". Kampanja ima dva segmenta, inspekcijski i informativni, pri čemu se inspekcijski dio provodi vršenjem inspekcijskih nadzora s ciljem poboljšanja zaštite na radu radnika zaposlenih putem agencija za privremeno zapošljavanje, dok se informativni dio se provodi u cilju podizanja svijesti o obvezama u provođenju zaštite na radu. Predviđeno je da se pri provođenju kampanje posebna pozornost posveti uvjetima na mjestu rada prije ustupanja radnika korisniku, procjenjivanju rizika i mjerama prevencije koje uključuju korištenje osobne zaštitne opreme, osposobljavanju za rad na siguran način sukladno rizicima prisutnima na mjestima rada, zdravstvenoj sposobnosti potrebnoj za obavljanje poslova s posebnim uvjetima rada te obvezi prijave ozljeda i profesionalnih bolesti nadležnim inspekcijskim i drugim državnim tijelima. ${ }^{32}$

Način i intenzitet ostvarivanja navedenih preventivnih aktivnosti različiti su u državama, ali se u svim državama pri vršenju ovih aktivnosti ostvaruje izravan kontakt između uposlenih, poslodavaca i inspektora. Taj kontakt se ostvaruje prilikom nadzora, u radnim prostorijama inspektora ili na zajedničkim tripartitnim vijećima. Komunikacija

i radnicima o najdjelotvornijim načinima poštivanja zakonskih odredbi. Čl. 3. st. 1. t. (b) Konvencije o inspekciji rada broj $81 ; 1$. Zadaci sistema inspekcije rada u poljoprivredi su: ... (b) davati tehničke informacije $i$ savjete poslodavcima i radnicima o najefikasnijim načinima poštivanja zakonskih odredbi. Čl. 6. st. 1. t. (b) Konvencije o inspekciji rada u poljoprivredi, broj 129.

29 Rihthofen, V. fon, op. cit., str. 19.

30 Članice će poduzeti ili promovirati edukativne kampanje sa ciljem da informiraju stranke kojih se to tiče, svim odgovarajućim sredstvima, o primjenjivim pravnim propisima i potrebi njihove striktne primjene kao i o opasnostima za život i zdravlje osoba koje rade u poljoprivrednim dobrima i o najviše odgovarajućim sredstvima izbjegavanja istih; čl. 14. st. 1. Preporuke o inspekciji rada u poljoprivredi, broj 133.

31 Čl. 14. st. 2. Preporuke o inspekciji rada u poljoprivredi, broj 133.

32 Čizmar, Đ., Europska kampanja Odbora viših inspektora rada (SLIC) 2017.-2019., Zagreb, Sigurnost, vol. 60, 3/2018, str. 269-271. 
inspekcije rada sa socijalnim partnerima može biti izravna, putem telefona ili e-maila. U pojedinim državama, kao dio proaktivnog pristupa, inspektori publiciraju u tiskanoj formi ili na web stranicama ${ }^{33}$ neka od najinteresantnijih i najčešće postavljanih pitanja ili tema, odnosno objavljuju stručne članke o radnom zakonodavstvu, posebice onome što je novo, kao i o najučinkovitijim načinima primjene propisa. Značajnu preventivnu ulogu inspektori rada vrše svojim predavanjima na seminarima ili stručnim skupovima. U vršenju preventivnih aktivnosti potrebno je stvoriti odgovarajući balans između, na jednoj strani, uvjeravanja poslodavaca, ali i uposlenih u ispravnost preventivnog postupanja, $\mathrm{i}$, na drugoj strani, korištenja prinude, odnosno vršenja represivne funkcije u cilju generalne prevencije. ${ }^{34}$

Kao što je ranije rečeno navedeno, posebno osjetljiva je oblast sigurnosti i zdravlja na radu, s obzirom na to da nepravilnosti u toj oblasti mogu dovesti do ozbiljnih posljedica po život i zdravlje ljudi, kako uposlenih tako i trećih osoba. Zbog toga je Preporukom br. 81 sugerirano državama članicama da osiguraju da svaka osoba koja želi otvoriti industrijske ili trgovačke objekte treba prethodno obavijestiti nadležni inspektorat rada. Tako, npr. u Republici Hrvatskoj Inspekciji rada je dana nadležnost da, kao javnopravno tijelo, sudjeluje u postupku izdavanja građevinske i uporabne dozvole za objekte namijenjene za rad na koje se primjenjuju propisi o zaštiti na radu. U takvom postupku izdavanja građevinske dozvole nadležna inspekcija rada provjerava usklađenost glavnog projekta sa posebnim propisima i/ili uvjetima te ukoliko su oni ispunjeni izdaje potvrdu.$^{35}$ One države članice koje takvo ovlaštenje nisu prenijele na inspekciju rada, isto su povjerile drugim državnim tijelima.

Specifičan oblik vršenja preventivne funkcije situacija je kada inspektor rada rješenjem naloži zabranu vršenja određene djelatnosti, aktivnosti ili proizvodnog procesa, jer ona može ugroziti sigurnost i zdravlje ljudi. Dakle, iako je naložena i kao takva obvezujuća za subjekt nadzora, ova je aktivnost preventivnog karaktera, budući da (još uvijek) nije nastupila štetna posljedica. ${ }^{36}$

33 Inspekcije rada povećano koriste mogućnosti koje se nude putem interneta da osiguraju tehničke informacije i savjete o sadržaju propisa o sigurnosti i zdravlju na radu i najefikasnijim sredstvima postupanja u skladu s istim. To je navedeno od strane vlada većeg broja država, uključujući Fidži, Francusku, Poljsku, Rumunjsku, Ukrajinu, Ujedinjeno Kraljevstvo $i$ Vijetnam. Report III (Part 1B) General Survey of the reports concerning the Labour Inspection Convention, Geneva, 2006., op. cit., str. 31.

34 U većini zemalja sa efikasnom inspekcijom rada postoji kreativno ambivalentan odnos između inspekcije rada i poslodavaca, pošto inspekcija nastoji da pažljivo izbalansira ubeđivanje $i$ prinudu. Iskustvo pokazuje da najisplativije i najtrajnije rezultate daje efikasno ubeđivanje poslodavaca da usvoje preventivne i zaštitne mere a time i progresivnu politiku pridržavanja propisa kao nešto što je u njihovom sopstvenom dugoročnom interesu. Perišić S., Funkcionisanje inspekcije rada i ekonomska kriza, Novi Pazar, Univerzitetska misao, 10/2011, str. 88.

35 Čizmar, Đ., Rad inspektora rada u postupcima izdavanja građevinske i uporabne dozvole, Zagreb, Sigurnost, vol. 56, 4/2014, str. 357-358. U slučaju da građevinsku dozvolu izdaje Ministarstvo graditeljstva i prostornoga uređenja, glavni projekt izdaje inspektor rada iz Sektora za nadzor u području zaštite na radu Središnjeg ureda Inspektorata rada, a ako građevinsku dozvolu izdaje nadležno upravno tijelo za poslove graditeljstva velikog grada, Grada Zagreba ili županije, potvrdu glavnog projekta izdaje mjesno nadležan inspektor rada u područnom uredu, odnosno ispostavi područnog ureda Inspektorata rada.

36 Opasnost može, ali ne mora, nastati kao rezultat nepridržavanja propisa. Ukoliko je sigurnost 
Preventivna aktivnost inspekcijskih službi može se ostvarivati i putem iniciranja izmjena određenih propisa, odnosno u davanju mišljenja ili učešću u izradi određenih propisa. Tako je npr. Federalna uprava za inspekcijske poslove u 2018. godini inicirala izmjene Zakona o radnom vremenu, obveznim odmorima mobilnih radnika i uređajima za evidentiranje u cestovnom prijevozu Bosne i Hercegovine, Zakona o radu (u cilju reguliranja instituta ,iznajmljivanja radne snage“), Pravilnika o privatnim agencijama za zapošljavanje te dala svoje mišljenje u svezi s prijedlogom Uredbe o postupku prijema u radni odnos u javnom sektoru u Federaciji Bosne i Hercegovine. ${ }^{37}$

\subsection{Korektivna funkcija inspekcije rada}

Korektivna funkcija inspekcije rada, kao reaktivna djelatnost koja se provodi u slučaju nepridržavanja propisa, ima za cilj ispravljanje, otklanjanje ili umanjenje posljedica nepravilnosti koje su počinili poslodavci. Kao što je to ranije navedeno, nepravilnost može nastati svakom radnjom kojom se postupa suprotno pravnoj normi.

Korektivnu funkciju inspekcije rada potvrđuje i Konvencija o inspekciji rada, broj $81,{ }^{38}$ i Konvencija o inspekciji rada (u poljoprivredi), broj $129,{ }^{39}$ koje isto, propisuju da su [i]nspektori rada ... ovlašteni poduzimati aktivnosti u cilju otklanjanja nedostataka, uočenih na postrojenju, alatu ili u metodama rada, za koje iz opravdanog razloga vjeruju da predstavljaju prijetnju za zdravlje ili sigurnost radnika. Međutim, treba istaći da korektivna funkcija nije ograničena samo na one nepravilnosti koje su prijetnja po zdravlje i sigurnost radnika.

Korektivnu funkciju inspektor rada vrši tijekom i nakon inspekcijskog nadzora. Kada prilikom vršenja inspekcijskog nadzora inspektor rada utvrdi određene manje nepravilnosti kod subjekta nadzora, dužan je iste evidentirati u zapisnik te onda, na osnovu diskrecionog ovlaštenja odlučiti da li je u konkretnom slučaju dovoljno usmeno upozoriti subjekt nadzora da ih je obvezan otklonititi ${ }^{41}$ ili će naložiti odgovarajuće upravne mjere. Praksa je pokazala da postoji potreba da se inspektorima rada omogući diskreciono odlučivanje kako bi svoje djelovanje mogli prilagoditi konkretnim okolnostima. U slučaju težih nepravilnosti, kao i kada subjekt nadzora nije postupio

i zdravlje radnika u neposrednoj opasnosti nema svrhe istraživati postojanje kršenja, prioritet postaje eliminacija opasnosti. U takvim slučajevima inspektori rada propisuje mjere koje mogu uključivati obustavu radova ili zatvaranje preduzeća, u zavisnosti od ozbiljnosti opasnosti. Svrha davanja direktnog ili indirektnog ovlaštenja inspektorima rada da nalažu takve mjere je prije svega da zaštiti radnike od opasnosti za njihovu sigurnost i zdravlje. Report III (Part 1B) General Survey of the reports concerning the Labour Inspection Convention, Geneva, 2006., op. cit., str. 35.

37 Godišnji izvještaj o radu Federalne uprave za inspekcijske poslove za 2018. godinu, str. 7, <www.fuzip.gov.ba/bundles/websitenews/gallery/files/37/1552313830Izvjestaj2018 compressed.pdf $>$.

38 Čl. 13. st. (1) Konvencije o inspekciji rada iz 1947. godine.

39 Čl. 18. st. (1) Konvencije o inspekciji rada (u poljoprivredi) iz 1969. godine.

40 Inspektori rada slobodno odlučuju hoće li izreći opomenu ili dati savjet umjesto pokretanja postupka ili predlaganja postupanja...; čl. 17. st. (2) Konvencije o inspekciji rada iz 1947. godine. Slično propisuje i čl. 22. st. (2) Konvencije o inspekciji rada (u poljoprivredi) iz 1969. godine. 
po usmenom upozorenju inspektora, inspektor rada će sačiniti rješenje kojim će subjektu nadzora naložiti određene upravne mjere, odnosno postupanja. Ovakva diskreciona ovlaštenja inspektora rada su vrlo važan instrument osiguranja poštovanja slova i duha zakona, jer omogućavaju da se u svakoj konkretnoj situaciji iznađu najadekvatnija rješenja. Ono što je vrlo bitno kod korištenja diskrecionih ovlaštenja je da se ne zloupotrebljavaju, bilo za osobnu korist ili kroz nepošteno kažnjavanje poduzeća. Kako bi se izbjegle eventualne zloupotrebe granice diskrecionog ovlaštenja inspektora moraju biti jasno i nedvojbeno definirane. ${ }^{41}$ Ovaj rizik može se umanjiti, npr. donošenjem vodiča za postupanje i pravila ponašanja inspektora te efikasnim stegovnim i/ili kaznenim sankcioniranjem u slučaju zloupotrebe ovih ovlaštenja. ${ }^{42}$

Ovisno o pravnom sistemu, različite su upravne mjere koje inspektori rada mogu naložiti. Najčešće upravne mjere koje inspektori rada nalažu u slučaju kada utvrde nepravilnosti su sljedeće: da se utvrđene nepravilnosti otklone (u određenom roku), da se poduzmu radnje koje je subjekt nadzora propustio poduzeti, da se zabrane određene radnje ili postupanja. U svakom konkretnom slučaju inspektori rada trebaju odrediti najadekvatniju mjeru, kojom će biti ispravljena ili otklonjena nepravilnost, odnosno umanjene njene posljedice. Pri određivanju odgovarajuće mjere posebno do izražaja dolazi primjena načela razmjernosti, budući da inspektor treba odrediti onu mjeru ili radnju koja je razmjerna nepravilnosti, a kojom se povoljnije za subjekt nadzora ostvaruje cilj i svrha inspekcijskog nadzora.

\subsection{Represivna funkcija inspekcije rada}

Kao što je već rečeno, nepoštovanje pravnih normi koje reguliraju oblast rada i sigurnosti na radu protupravno je djelo. ${ }^{43}$ Represivna funkcija inspekcije rada ostvaruje se, prvenstveno, izricanjem sankcije poslodavcima čije je postupanje suprotno odredbama radnoga zakonodavstva, ali i poduzimanjem drugih mjera koje imaju za cilj vršenje represivne funkcije. Treba istaći da su sankcije samo jedno od sredstava koje stoje na raspolaganju inspektorima. U vršenju represivne funkcije inspektori rada mogu vršiti aktivnosti vezane za upravne, prekršajne, građanske i kaznene postupke. ${ }^{44}$ Osim klasičnih pravnih aktivnosti, represivna funkcija se može ostvariti i kroz izvanpravne aktivnosti inspekcije rada koje se mogu doticati poslovnih interesa poduzeća, kao što su onemogućavanje učešća u postupcima javnih nabava, uskraćivanjem subvencija, poticaja i državne pomoći, oduzimanjem dozvola za obavljanje određenih poslova, privremenom ili trajnom obustavom radova ili poslovne aktivnosti. ${ }^{45}$

Da bi ostvarile svoju svrhu sankcije moraju biti odgovarajuće po obliku i visini,

41 Rihthofen, V. fon, op. cit., str. 92.

42 Vega Maria, L., Rene, R., Labour inspection sanctions: Law and practice of national labour inspection systems, Geneva, International Labour Organisation, 2013., str. 19.

43 Učur, M., Zaštita osobe u radnom odnosu od načela do realizacije, Zbornik Pravnog fakulteta Sveučilišta u Rijeci, vol. 29, 1/2008, str. 558.

44 Vega Maria, L., Rene, R., op. cit., str. 19.

45 ibid., str. iv. 
te osim što se izriču one se moraju i učinkovito izvršiti. ${ }^{46}$ Kredibilitet inspekcije rada ovisi o dva bitna elementa: sposobnosti da savjetuje poslodavca i radnike o najdjelotvornijim načinima usklađivanja postupanja s radnim zakonodavstvom (preventivna i korektivna funkcije) te o odabiru i primjeni odgovarajućih mehanizama izvršenja sankcija (represivna funkcija). ${ }^{47}$ Time se još jednom potvrđuje postojanje komplementarnosti između preventivne i represivne funkcije inspekcijskog nadzora. ${ }^{48}$

Nesporno je da su sankcije sredstvo koje stoji na raspolaganju inspekciji rada. Međutim, da bi se uspješno vršila uloga inspekcije rada potrebno je utvrditi kaznenu politiku, koja će obuhvatiti mjere potrebne radi usklađivanja postupanja sa zakonom, ispravljanje utvrđenih nepravilnosti i odvraćanje od budućih kršenja. Jedna od glavnih prepreka koja rad inspektora čini neučinkovitim jeste nepostojanje odvraćajućeg sustava sankcija koje su na raspolaganju inspektoru. ${ }^{49}$ Naime, u praksi, pitanje sankcija najčešće nije dovoljno jasno i kvalitetno uređeno te se inspektorima rada stoga mora omogućiti određena razina diskrecije pri utvrđivanju odgovarajućih sankcija u odnosu na konkretnu nepravilnost. Ta diskreciona ovlaštenja u svojoj suštini praktična su primjena načela razmjernosti, budući da inspektor rada konkretno ocjenjuje da se cilj i svrha nadzora ostvaruju onim mjerama i sankcijama koje su razmjerne učinjenim nepravilnostima. Načelo razmjernosti nalaže inspektoru da među mjerama koje u okviru propisa može izreći izabere onu mjeru koja je povoljnija za subjekt nadzora, odnosno da ostavi prikladan rok za otklanjanje nepravilnosti. Vrsta i visina sankcija su nerijetko loše utvrđene, tako da su ili preblage da bi mogle imati odvraćajuće djelovanje ili prestroge što opet utječe na to da zbog svoje disproporcije (kao društveno neopravdane i neprihvatljive) najčešće i ne budu izvršene. Sankcije moraju biti tako prilagođene da natjeraju poslodavca da, kada se utvrdi nepravilnost, spontano ili po nalogu inspektora rada, poduzme korektivne aktivnosti te da ga odvrate od budućih kršenja. ${ }^{50}$

Sustav sankcija, kao dio represivne funkcije inspekcije rada, je važno sredstvo koje podržava poštovanje zakona. On se uspostavlja na temelju vrednovanja društvene opasnosti i štetnosti nezakonitog ponašanja, s jedne strane, i težine sankcija, s druge

46 ibid., str. 3.

47 Report III (Part 1B) General Survey of the reports concerning the Labour Inspection Convention, Geneva, 2006., op. cit., str. 93.

48 Sistem inspekcije rada ima dvoju ulogu. U jednu ruku, on nadzire izvršenje pravnih odredbi (uključujući uslove rada, uređenje radnog odnosa, standardne zdravlja i sigurnosti). U drugu ruku, on pruža informacije obuke i savjete radnicima, poslodavcu i njihovim predstavnicima. U ovom okviru sankcije koje su na odgovarajući način utvrđene u skladu sa regulatornim $i$ ekonomskim uslovima države su komplementarne općoj svrsi promocije usklađivanja sa radnim zakonodavstvom. Vega Maria, L., Rene, R., op. cit., str. 3. Mjere prevencije i izvršsenja sankcija su komplementarne u odnosu na opću svrhu promocije radnih standarda. Bitno je za sistem administracije rada uspostaviti odgovarajući i blagovremen proces za utvrđivanje i izvršenje kazni, kao i blagovremen postupak koji će se provoditi u skladu sa principima postupka. Provisional Record 19, International Labour Conference 100th Session, Geneva, June 2011., str. 91-92.

49 Vega Maria, L., Rene, R., op. cit., str. 5.

50 ibid., str. 3. 
strane. ${ }^{51}$ Širina spektra sankcija za kršenje radnog zakonodavstva, koje mogu izricati inspektori rada ili sudovi, zavisi o državi, njenom uređenju i organizaciji te politici u oblasti rada.

Širina spektra sankcija je izuzetno bitna za efektivnost ukupnog sustava sankcija. ${ }^{52}$ Naime, uzak spektar sankcija, posebno kada se radi samo o jednoj vrsti sankcija, onemogućava ostvarivanje represivne funkcije. Iako može izgledati kao paradoks, u tom slučaju što je sankcija teža to više dovodi do neprimjenjivanja propisa od strane inspektora. Jer za neke manje prekršaje politički je nemoguće $i$ moralno neprihvatljivo ${ }^{53}$ primjenjivati takve sankcije, budući da ne postoji razmjer između prekršaja i sankcije. Inspekcijske službe koje imaju na raspolaganju samo jednu sankciju u tim situacijama će se, najčešće, uzdržati od primjene sankcije, što negativno utječe na sustav sankcija. Najoptimalnije bi bilo da za svaku vrstu povrede postoji određena vrsta ili visina sankcije, koja odgovara značaju i težini prekršaja.

Iako sve inspekcije rada u okviru svojih ovlaštenja vrše represivnu funkciju, sustav sankcija nije jedinstven, nego zavisi o politici u oblasti rada svake od država. Tako u nekim državama, npr. inspektori rada ne mogu samostalno izricati novčane kazne, nego mogu podnositi samo prekršajne prijave ili obavještavati resorna ministarstva da podnose takve prijave. ${ }^{54}$ Takvu mogućnost predviđa i Konvencija o inspekciji rada (u poljoprivredi) iz 1969. godine koja propisuje da ako inspektori rada nisu ovlašteni pokretati prekršajne postupke, onda moraju imati ovlasti podnositi izvješća o prekršajima onim tijelima koja su nadležna za pokretanje takvih postupaka..$^{55}$ Ipak, općenito, većina nacionalnih zakonodavstava daje inspektorima ovlaštenje da na licu mjesta izriču novčane sankcije, odnosno izdaju prekršajne naloge. ${ }^{56}$

Najčešća sankcija koju inspekcije rada mogu izricati je novčana kazna. U nekim slučajevima su te kazne niske pa nisu odgovarajuće sredstvo odvraćanja, posebno za srednja i velika poduzeća koja ih mogu platiti bez poteškoća. ${ }^{57} \mathrm{U}$ tim situacijama

51 Da bi bile kredibilne, važno je da kazne budu definisane u odnosu na prirodu i težinu prekršaja. Report III (Part 1B) General Survey of the reports concerning the Labour Inspection Convention, Geneva, 2006., op. cit., str. 96.

52 Izbjegavanje saradnje je vjerovatno manje privlačan prijedlog za biznis kada susreće regulatora sa piramidom izvršenja nego kada se susreće sa regulatorom koji ima samo jednu opciju zastrašivanja. Ayres I., Braithwaite J., op. cit., str. 36.

53 loc. cit.

54 Unekim slučajevima, inspektori imaju direktno pravno ovlaštenje da izriču kazne zbog prekršaja koje su utvrdili tokom inspekcijskog nadzora. To nije slučaj u svim državama. U Francuskoj, na primjer, inspektori rada nemaju pravni osnov za izricanje novčanih kazni, kao što policajac može kada izdaje prekršajni nalog. Točnije, francuski inspektori mogu jedino obavijestiti o postojanju prekršaja i predložiti aktivnosti odgovarajućem upravnom ili sudskom organu, koji sam ima ovlaštenje da kazni ili izrekne neku drugu odgovarajuću sankciju. Ova vrsta procedure ograničava diskreciju inspektora u radu sa prekršiteljima na licu mjesta, ali se može smatrati sredstvom osiguranja trasparentnosti $i$ upravne konzistentnosti u izricanju novčanih kazni. To može dalje pomoći (prividno) umanjenju mogućnosti inspektorima da zloupotrebljavaju njihova ovlaštenja iznuđujući mito, dodajući nadzorno odobrenje. Vega Maria, L., Rene, R., op. cit., str. 15.

55 Čl. 23. Konvencije o inspekciji rada (u poljoprivredi) iz 1969. godine.

56 Vega Maria, L., Rene, R., op. cit., str. 15.

57 ibid., str. 7. 
subjekt nadzora može, suprotno politici u određenoj oblasti, samostalno vrednujući odnos između koristi i štete koju može imati zbog nepropisnog ponašanja, da ocjeni da mu je nastavak nepropisnog ponašanja ili postupanja prihvatljiviji od izrečene sankcije. Time se urušava društveni sustav i politika države u oblasti rada, te ozbiljno narušava autoritet države. Novčana kazna je jedno od osnovnih sredstava represije koje inspektori rada koriste u cilju usklađivanja postupanja subjekata nadzora u skladu sa zakonom, odnosno kao kaznu zbog kršenja propisa. U najvećem broju država nacionalno zakonodavstvo izričito navodi za koje nepravilnosti se mogu izricati novčane kazne. Zakonima je uobičajeno predviđen opseg novčane kazne (npr. od 50 do 1.000 eura) ili maksimalni iznos kazne za određene nepravilnosti. Bitno je da novčana sankcija bude adekvatna, da se ne dođe u situaciju da je poslodavcu prihvatljivije da plati novčanu kaznu nego da svoje postupanje uskladi sa zakonom. ${ }^{58}$ Novčana kazna treba biti dovoljno fleksibilna da se prilagodi okolnostima prekršaja, jer kažnjavanje za različite nepravilnosti istom novčanom kaznom ne može biti prihvaćeno kao društveno prihvatljivo i opravdano.

Pored novčane kazne, druga je najčešća mjera privremeno ili trajno obustavljanje rada subjektu nadzora. Do primjene ove mjere najčešće dolazi u oblasti sigurnosti na radu, u situacijama kada je zbog nepravilnosti ugrožen život i zdravlje radnika ili drugih osoba. S obzirom na težinu navedene mjere, to nije standardno ovlaštenje inspekcije rada, odnosno može biti podložno dodatnim odobrenjima drugih državnih tijela. ${ }^{59}$

U Europskoj uniji države članice uobičajeno koriste kombinaciju kaznenih i upravno-prekršajnih sankcija. Upravno-prekršajne sankcije dominantne su u Austriji, Danskoj, Njemačkoj, Italiji, Litvi, Portugalu, Slovačkoj i Španjolskoj. Kaznene sankcije igraju ulogu u slučajevima težih kršenja radnog zakonodavstva, a posebno u oblasti zaštite života i zdravlja i sigurnosti na radu. S druge strane, u Francuskoj kaznene sankcije imaju važnu ulogu. ${ }^{60}$ Većina kaznenih zakonodavstava sadrži odredbe o kaznenim djelima vezanim za radne odnose.

Posebne sankcije predviđene su zbog onemogućavanja rada inspektora. Onemogućavanje rada inspektorima može se manifestirati onemogućavanjem pristupa prostorijama, dokumentaciji ili strojevima, odnosno odbijanjem suradnje i davanja informacija. Odredbama obje konvencije o inspekciji rada propisano je da se nacionalnim zakonodavstvima država članica moraju propisati kazne za onemogućavanje rada inspektora te da se moraju učinkovito i provoditi. ${ }^{61}$ Pojedine

58 Beznačajna novčana kazna je pogodna da bude ignorirana i ima malo ili nimalo utjecaja na ponašanje poslodavca. S druge strane, teška novčana kazna, ako se primjenjuje striktno, može ugroziti održivost poduzeća i poslove njegovih radnika...; ibid., str. 15.

59 Npr. u Albaniji odluku o obustavi rada koju je donio inspektor rada mora u roku od 48 potvrditi generalni inspektor.

60 ibid., str. 8-9.

61 Nacionalnim zakonima ili drugim propisima moraju se propisati odgovarajuće kazne za kršenje zakonskih odredaba za čije su provođenje nadležni inspektori rada, kao i za ometanje inspektora rada u obavljanju njihovih dužnosti, te se one moraju efikasno provoditi; čl. 18. Konvencije o inspekciji rada iz 1947. godine. Slično je propisano i odredbom čl. 24. Konvencije o inspekciji rada (u poljoprivredi) iz 1969. godine. 
države (npr. Belgija) su takvo postupanje definirale kao kazneno djelo.

\section{MOGUĆNOSTI JAČANJA PREVENTIVNE FUNKCIJE KROZ ZAKONODAVNE INTERVENCIJE U FEDERACIJI BOSNE I HERCEGOVINE}

Organizacija i nadležnosti inspekcije rada na teritoriju Federacije Bosne i Hercegovine regulirane su prvenstveno odredbama Zakona o inspekcijama Federacije Bosne i Hercegovine, ${ }^{62}$ županijskim zakonima o inspekcijama, ${ }^{63}$ Zakonom o radu (Federacije Bosne i Hercegovine) ${ }^{64}$ te Zakonom o zaštiti na radu. ${ }^{65}$

Glede ovlaštenja za vršenje inspekcijskog nadzora propisano je da se djelokrug rada federalnih inspekcija utvrđuje propisima Federacije Bosne i Hercegovine, kao i propisima Bosne i Hercegovine koji propisuju da inspekcijski nadzor vrše entitetske inspekcije i inspekcije Brčko Distrikta Bosne i Hercegovine, kao i drugim propisima kojima je utvrđena nadležnost federalnih inspekcija za određenu upravnu oblast. Federalna inspekcija vrši inspekcijski nadzor nad primjenom propisa kojima je utvrđena nadležnost entitetskih inspekcija za vršenje inspekcijskog nadzora te, izuzetno, i onih federalnih propisa čiji je nadzor u nadležnosti županijskog inspektora, ako županijsko tijelo za inspekcijske poslove nema inspektora iz te oblasti. Zakon o inspekcijama Federacije Bosne i Hercegovine, kojim je uređeno vršenje inspekcijskog nadzora iz nadležnosti federalnih tijela uprave, inspekcijski poslovi federalnih inspekcija i njihov djelokrug, jedinstveni postupak inspekcijskog nadzora u Federaciji Bosne i Hercegovine radi osiguranja izvršenja zakona i drugih propisa, organizacija Federalne uprave za inspekcijske poslove i rukovođenje, prava, obveze i odgovornosti inspektora, prava i obveze subjekata nadzora, odnosi između Federalne uprave i županijskih inspekcijskih tijela, preventivno djelovanje inspektora u vršenju inspekcijskog nadzora i druga pitanja značajna za funkcioniranje inspekcijskog sustava Federacije Bosne i Hercegovine ${ }^{66}$ dobar je temelj za odgovarajuće vršenje preventivne funkcije inspekcije rada.

Iako Zakon o inspekcijama Federacije Bosne i Hercegovine prepoznaje posebne funkcije inspekcijskog nadzora, zakoni koji reguliraju nadležnosti i postupanja inspekcija rada, Zakon o radu, a posebice Zakon o zaštiti na radu, ne posvećuju posebnu pažnju preventivnoj funkciji inspekcije rada. Posebno je to izraženo u oblasti zaštite na radu, budući da je ova oblast u Federaciji Bosne i Hercegovine još uvijek regulirana Zakonom o zaštiti na radu iz 1990. godine, koji je u svim njegovim segmentima, a posebice vezano za preventivno djelovanje, prevladan. Iako je radno zakonodavstvo u Bosni i Hercegovini od stjecanja neovisnosti do danas

62 Sl. novine $\mathrm{FBiH}$, br. $73 / 14$.

63 Sedam od deset županija u Federaciji Bosne i Hercegovine je donijelo svoje zakone o inspekcijama, i to: Zapadnohercegovačka županija, Zeničko-dobojski kanton, Unsko-sanski kanton, Tuzlanski kanton, Posavska županija' Bosansko-podrinjski kanton te Kanton Sarajevo.

64 Sl. novine $\mathrm{FBiH}$, br. 26/16 i 89/18.

65 Sl. list SR BiH, br. 22/90.

66 Čl. 1. Zakona o inspekcijama u Federaciji Bosne i Hercegovine. 
imalo dinamičan i raznovrstan razvoj u cilju njegova prilagođavanja tržišnom načinu privređivanja i prilagodbi odredbama komunitarnog prava, to nažalost nije bio slučaju i u oblasti zaštite na radu. U praksi su još poodavno i radnici i poslodavci i Vlada Federacije Bosne i Hercegovine, ${ }^{67}$ prepoznali potrebu za donošenjem novog zakona, kojim će se regulirati oblast sigurnosti i zaštite na radu te posebno apostrofirati prevencija povreda na radu i profesionalnih oboljenja. Nažalost, do danas takav propis nije donesen.

Ipak, upravo ta nužnost donošenja novog zakona o zaštiti na radu može biti prilika za inovativnije uređenje ove oblasti, pri čemu će se, cijeneći da je život i zdravlje radnika velika društvena vrijednost pitanju preventivnih aktivnosti općenito, a posebno preventivnih aktivnosti inspekcije rada pridati dužna pažnja.

\section{ZAKLJUČAK}

Inspekcijske službe imaju veliki društveni i gospodarski značaj. One imaju dvojak cilj i ulogu. S jedne strane nadziru i osiguravaju dosljednu primjenu propisa, dok s druge identificiraju slabosti i nedostatke tih istih propisa u praktičnoj primjeni, a sve u cilju njihovog prilagođavanja realnim društvenim potrebama. Uloga i značaj inspekcijskih službi zahtijevaju da se pitanju učinkovitosti njihovog rada posveti dužna pažnja te da se, između ostaloga, u tom cilju razmotri i pitanje mogućnosti unaprjeđenja njihovog rada.

Intenzitet vršenja temeljnih funkcija inspekcijskog nadzora u oblasti rada, radnih odnosa i sigurnosti na radu je u značajnoj mjeri specifičan u odnosu na ostale oblasti inspekcijskog nadzora. U ovoj oblasti primarna funkcija bi trebala biti preventivna funkcija. Šteta koja je nastala, posebice u oblasti zaštite zdravlja i sigurnosti na radu uposlenih i drugih osoba, u najvećem broju slučajeva ne može se ispraviti ili otkloniti, dok se određene posljedice mogu umanjiti. U tim slučajevima, šteta koja je nastala na životima i zdravlju ljudi (uposlenih ili trećih osoba) ima ogromne društvene i gospodarske implikacije. Iako i represivna funkcija ima svoju ulogu, u oblasti rada, radnih odnosa i sigurnosti na radu, ona se mora promatrati prvenstveno kroz prizmu generalne i specijalne prevencije. Resorna ministarstva rada, kao nositelji javnih politika u ovoj oblasti, moraju mnogo više i učinkovitije djelovati na promoviranju prevencije te $\mathrm{u}$ tom smislu usmjeravati i poticati i aktivnosti inspekcije rada.

Prevladan normativni okvir u Federaciji Bosne i Hercegovine u oblast sigurnosti i zaštite na radu ne osigurava adekvatno preventivno postupanje inspekcija rada, međutim, upravo nužnost donošenja nove regulative o zaštiti na radu može biti prilika za inovativnije uređenje ove oblasti.

67 Vlada Federacije Bosne i Hercegovine više je puta (2007., 2009. i 2016. godine) utvrđivala i u parlamentarnu proceduru upućivala nacrt Zakona o sigurnosti i zdravlju na radu. 


\section{Knjige i članci}

\section{LITERATURA}

1. Anđelković, Branislav, Uloga nadzora i inspekcije zaštite na radu u uslovima tranzicije na tržišnu ekonomiju - iskustva Republike Srbije, Niš, Safety Engineernig, vol. 4, 1/2014, str. 51-54.

2. Ayres, Ian, Braithwaite, John, Responsive regulation: Transcending the deregulation debate, New York-Oxford, Oxford University Press, 1992.

3. Bojanić, Igor, Mrčela, Marin, Svrha kažnjavanja u kontekstu šeste novele Kaznenog zakona, Zagreb, Hrvatski ljetopis za kazneno pravo i praksu, vol. 13, broj 2/2006, 2006., str. 431-449.

4. Borković, Ivo, Upravno pravo, Zagreb, Narodne novine, 2002.

5. Burazin, Luka, Hegelov prinos suvremenom odštetnom pravu sa stajališta opće teorije i filozofije prava, Hrvatska pravna revija, vol. XI, 2/2011, str. 81-84.

6. Cesar Rosando, Marzan, Of Labour Inspectors and Labour Judges: Chilean Labour Law Enforcement After Pinochet (And What the United States Can Do To Help) (Symposium), St. Louis University Law Journal, vol. 54, 497/2009, str. 497-524.

7. Čizmar, Đuro, Europska kampanja Odbora viših inspektora rada (SLIC) 2017.-2019., Zagreb, Sigurnost, vol. 60, 3/2018, str. 269-271.

8. Čizmar, Đuro, Rad inspektora rada u postupcima izdavanja građevinske i uporabne dozvole, Zagreb, Sigurnost, vol. 56, 4/2014, str. 357-359.

9. Dedić, Sead, Upravno pravo Bosne i Hercegovine, Bihać - Sarajevo, Pravni fakultet u Bihaću, Magistrat, 2000.

10. Dedić, Sead, Gradaščević-Sijerčić, Jasminka, Radno pravo, drugo izmijenjeno i dopunjeno izdanje, Sarajevo, Magistrat, 2005.

11. Ivošević, Zoran, Radno pravo, Osmo izmenjeno i dopunjeno izdanje, Beograd, Pravni fakultet Univerziteta Union u Beogradu i Javno preduzeće Službeni glasnik, 2015.

12. Jacobs, Scott, Cordova, César, Good Practices for Business Inspections - Guidelines for Reformers, Washington, World Bank Group, Small and Medium Enterprise Department, 2006.

13. Jacobs, Scott, Cordova, César, Good Practices for Business Inspections: Guidelines for Reformers, Small and Medium Enterprise Department, Washington, World Bank Group, 2006.

14. Lukić, Radomir, Košutić, Budimir, Uvod u pravo, XIX. izdanje, Beograd, Službeni list SCG, 2003.

15. Perišić, Saša, Funkcionisanje inspekcije rada i ekonomska kriza, Novi Pazar, Univerzitetska misao, 10/2011.

16. Perišić, Saša, Organizacija i principi inspekcijskog nadzora, doktorska disertacija, Niš, Pravni fakultet u Nišu, 2011.

17. Pires, Roberto, Labour inspection and development: Some reflections, Geneva, International Labour Organisation, 2011.

18. Provisional Record 19, International Labour Conference 100th Session, Geneva, June 2011.

19. Report of the Committee of Experts on the Application of Conventions and Recommendations (Article 19, 22 and 35 of the Constitution), International Labour Office, 50th Session, Geneva, 1966, Report III (Part IV): Labour inspection in industry.

20. Report III (Part 1B) General Survey of the reports concerning the Labour Inspection Convention, Geneva, 2006.

21. Rihthofen, Volfgang fon, Inspekcija rada - Vodič za profesiju, Beograd, Ministarstvo rada, zapošljavanja i socijalne politike Republike Srbije, 2005. 
22. Rozić, Ivo, Mehmedović, Emir, Uticaj organizacije inspekcijskih službi na učinkovitost i ostvarivanje funkcija inspekcijskih nadzora - primjer inspekcija rada u Bosni i Hercegovini, Godišnjak Pravnog fakulteta Univerziteta „Džemal Bijedić“ u Mostaru, god. I, 1/2017, str. 116-131.

23. Stojanović, Zoran, Preventivna funkcija krivičnog prava, Beograd, Crimen - Časopis za krivične nauke, 1/2011, str. 3-25.

24. Učur, Marinko, Neki posebni subjekti i odnosi po Zakonu o zaštiti na radu, Zbornik Pravnog fakulteta Sveučilišta u Rijeci, vol. 36, 1/2015, str. 533-546.

25. Učur, Marinko, Zaštita osobe u radnom odnosu od načela do realizacije, Zbornik Pravnog fakulteta Sveučilišta u Rijeci, vol. 29, 1/2008, str. 557-578.

26. Vega, Maria Luz, Rene, Robert, Labour inspection sanctions: Law and practice of national labour inspection systems, Geneva, International Labour Organisation, 2013.

\section{Propisi}

1. Konvencija o inspekciji rada iz 1947. godine, broj 81 (Sl. list FNRJ - Međunarodni ugovori, br. 5/56 - u pravni sustav Bosne i Hercegovine preuzeta 2. lipnja 1993. godine na temelju notifikacije o sukcesiji međunarodnih ugovora bivše SFRJ)

2. Konvencija o inspekciji rada (u poljoprivredi) iz 1969. godine, br. 129 (Sl. list SFRJ, br. 22/75 - u pravni sustav Bosne i Hercegovine preuzeta 2. lipnja 1993. godine na temelju notifikacije o sukcesiji međunarodnih ugovora bivše SFRJ)

3. Preporuka o inspekciji rada iz 1947. godine, br. 81

4. Preporuka o inspekciji rada u poljoprivredi iz 1969. godine, br. 133

5. Zakon o inspekcijama Federacije Bosne i Hercegovine (Sl. novine FBiH, broj 73/14)

6. Zakon o radu (FBiH) (Sl. novine FBiH, br. 26/16 i 89/18)

7. Zakon o zaštiti na radu (Sl. list SR BiH, br. 22/90) 


\author{
Ivo Rozić* \\ Emir Mehmedović**
}

Summary

\title{
SPECIALITIES OF INSPECTION FUNCTIONS PERFORMANCE IN THE AREAS OF WORK, WORK RELATIONS AND OCCUPATIONAL SAFETY
}

In this paper, authors deal with the problem of intensity of inspection supervision basic function performance (preventive, corrective and repressive function), primarly in the context of the labor inspection. Although these functions are common for inspection supervision in general, scope and intensity of their performance depend on the area of inspection supervision. In addition, and in the frame of specific area, the scope of use of the aforementioned functions depends also on the degree (and quality) of respective sectoral policy, as well as on the organization of the inspection supervision. Due to its social and economic importance, as well as influential subjects (business societies and employees) - areas of work, work relations and occupational safety require a tailored approach to inspection supervision. In the field of work and labor affairs, preventive function has, or at least should have, (more) dominant role in regard to corrective and repressive function of inspection supervision.

Keywords: inspection service; sectoral policy; preventive function; corrective function; repressive function.

Zusammenfassung

\section{BESONDERHEITEN DER DURCHFÜHRUNG DER AUFSICHT IM BEREICH DER ARBEIT, ARBEITSVERHÄLTNISSE UND DES ARBEITSSCHUTZES}

Der Beitrag bespricht die Frage der Intensität der Durchführung der Arbeitsaufsicht, insbesondere ihre vorbeugende, korrektive und repressive Funktion. Obwohl diese Funktionen allen Bereichen der Aufsichten gemeinsam sind, hängt der Umfang und die Intensität der Durchführung genannter Funktionen vom Bereich, in dem die Aufsicht durchgeführt wird, ab. Ebenfalls hängt der Umfang der Nutzung

* Ivo Rozić, Ph.D., Associate Professor, University of Mostar, Faculty of Law, ivo_rozic@yahoo. com.

** Emir Mehmedović, Ph.D., Assistant Professor, University of Sarajevo, Faculty of Administration, emir.mehmedovic@fu.unsa.ba. 
genannter Funktionen der Aufsicht sowohl von der Entwicklung (und Qualität) der sektoralen Politik als auch von der Form der Organisation des Aufsichtsamtes ab. Wegen seiner gesellschaftlichen und wirtschaftlichen Bedeutung sowie auch der von ihm beeinflussten Subjekte (wirtschaftliche Gesellschaften und Beschäftigte) verlangt der Bereich der Arbeit, Arbeitsverhältnisse und Arbeitssicherheit einen angemessenen Ansatz bei der Aufsicht. Im Bereich der Arbeit, Arbeitsverhältnisse und Arbeitssicherheit spielt oder sollte die vorbeugende Funktion der korrektiven und repressiven Funktionen der Aufsicht gegenüber die wichtigste Rolle spielen.

Schlüsselwörter:Aufsichtsamt; sektorale Politik; vorbeugende Funktion; korrektive Funktion; repressive Funktion.

Riassunto

\section{LE SPECIFICITÀ DELL'ESPLETAMENTO DELLE FUNZIONI DI CONTROLLO NELL'AMBITO DEL LAVORO, DEI RAPPORTI DI LAVORO E DELLA SICUREZZA SUL LAVORO}

Nel lavoro si disamina la questione dell'intensità dell'espletamento delle funzioni ispettive di controllo - preventive, correttive e repressive nel contesto dell'ispezione del lavoro. Benché rappresentino funzioni comuni a tutte le autorità ispettive di controllo, la portata e l'intensità di tali funzioni dipende dalle funzioni cui siano deputati i singoli ispettorati. Oltre a ciò, nel contesto di una determinata funzione, l'ampiezza dell'utilizzo delle attività ispettive di controllo dipende anche dal grado di sviluppo (e di qualità) della politica settoriale, come anche della forma di organizzazione del servizio ispettivo. In ragione del suo significato sociale ed economico, come anche dei soggetti sui quali sortisce la propria influenza (società commerciale e lavoratori). Il lavoro, i rapporti di lavoro e la sicurezza sul lavoro esigono un approccio adattato nell'ambito del controllo ispettivo. Nel lavoro, nei rapporti di lavoro e nella sicurezza sul lavoro la funzione preventiva ha, o perlomeno dovrebbe avere, un ruolo preponderante rispetto alle funzioni di controllo correttiva e repressiva.

Parole chiave: autorità ispettive; politica settoriale; funzione preventiva; funzione correttiva; funzione repressiva. 
